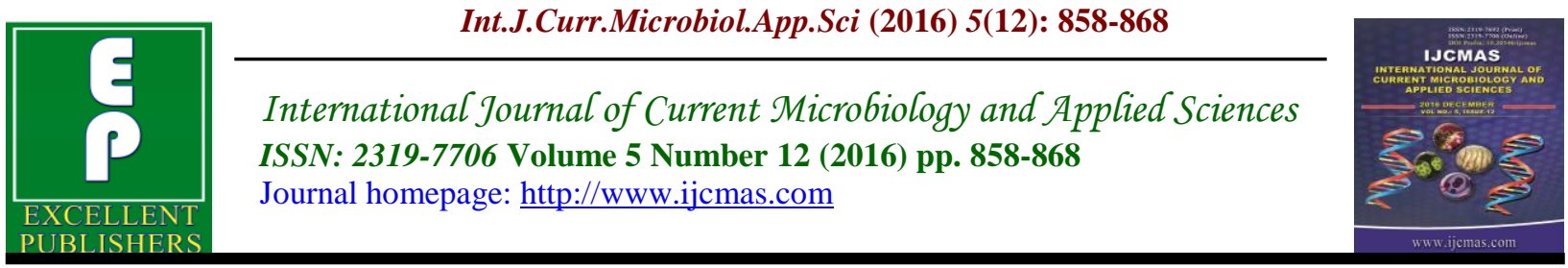

Original Research Article

http://dx.doi.org/10.20546/ijcmas.2016.512.094

\title{
In vitro Cultivation of Potato Plants
}

\author{
Ibrahim A. Ibrahim*, H.A. Emara, A.A. Nower and A.Y. Abodiab \\ Genetic Engineering and Biotechnology Research Institute \\ University of Sadat City, Egypt \\ *Corresponding author
}

\section{Keywords}

Solanum tuberosum, MS salt strength, gelling agent (agar and gelrite) light intensity, calcium pantothenate, Silver thiosulfate (STS).

\begin{tabular}{l}
\hline Article Info \\
\hline Accepted: \\
25 October 2016 \\
Available Online: \\
10 December 2016
\end{tabular}

\section{A B S T R A C T}

The in vitro growth and development of potato plants are determined by a number of complex factors: the genetic make-up of the plant, nutrients: water, macro- and micro-elements, and sugars as well as physical growth factors: light, temperature, $\mathrm{pH}, \mathrm{O} 2$ and $\mathrm{CO} 2$ concentrations and Some organic substances. Two potato cultivars namely, Santana and Innovator were used to study the effect of MS salt strength, gelling agent (agar and gelrite),calcium pantothenate as well as silver thiosulfate ( STS) and light intensity as physical growth factors on in vitro growth and development of potato meristem and shoot tip necrosis. There is no significant difference in plant length of two cultivars under different MS salt strength but the significantly effect was appeared in number of leaves at MS full salt strength. The opposite effect was occurred in root formation where 1/4 MS recorded the best result for root formation with significant difference among the treatments. Shoot tip necrosis was affected by MS salt strength, calcium pantothenate and STS. Nutrient medium supplemented with $2.5 \mathrm{~g} / \mathrm{l}$ agar $+1 \mathrm{~g} / \mathrm{l}$ gelrite recorded the best growth for shoot formation estimated as plant length, shoot number and number of leaves as well as root number. The best medium for in vitro growth of potato cultivars ( Innovator and Santana) was MS basal medium at full salt strength solidified with $2.5 \mathrm{~g} / \mathrm{l}$ agar $+1 \mathrm{~g} / \mathrm{l}$ gelrite $+2 \mathrm{mg} / \mathrm{l}$ cacium pantothenate $+0.5 \mathrm{mg} / \mathrm{STS}$ at $3000 \mathrm{Lux}$ and $22{ }^{\circ} \mathrm{C}$ which reduced shoot tip necrosis and improved in vitro growth. Potato plantlets produced in vitro were transferred to plastic pots $(6 \mathrm{~cm}$ diameter $)$ filled with peat moss, perlite and washed sand at equal volume for acclimatization under controlled green house. The survival percentage was more $80 \%$ after four weeks and the survival potato plants were transferred to plastic pots $(25 \mathrm{~cm}$ diameter $)$ for more growth and mintuber formation where potato plants grow well in the greenhouse

\section{Introduction}

Potatoes (Solanam tuberosum L.) are the most important vegetable crop in the world and in Egypt as well. Potato belongs to the family Solanaceae which includes tomato, eggplant, and peppers.
It is an annual herbaceous and short duration crop that produces large amount calories in a short period of time. The edible part of the plant is the tuber, which is formed at the end of underground stems called stolon. It is 
used as cheap food, industrial raw material, animal feed, and seed tuber. It is the most important cultivated food after wheat, rice and maize, and the most important dicotyledonous crop (Khatun et al., 2003 and Abdel Alleam, 2015). Potato crop is susceptible to many of viral, fungal and bacterial diseases in addition to pest infestation under local conditions. This infection and infestation by insects affect dramatically on quantity and quality of potato production. Control measurement of diseases and pests traditionally apply hazard chemicals which have negative impact on the environment and farmer and customer health. It well known that Egypt imported potato seeds for production of table potato. This production for local consumption and for exportation to Europe and Arab market (about 250000 ton annually). Recently for summer season (2015) Egypt imported about 150000 ton of potato seeds from Europe. This huge amount of seeds have negative influence on national economy and national hard currency. The alternative available approach for production of certified potato seeds is only way to solve the problem using micro-propagation in vitro technology. Biotechnology can contribute to solution of these problems and provide great benefits to potato farmers. The regeneration of plants from cell and tissue culture represent an essential component of biotechnology and have the potential not only to improve the existing cultivars, but also for the generation of novel plants in a comparatively short period of time compared to conventional breeding method (Abdelaleem, 2015).

The in vitro growth and development of potato (Solanum tuberosum L.) plants are determined by a number of complex factors: the genetic make-up of the plant, nutrients: water, macro- and micro-elements, and sugars as well as physical growth factors: light, temperature, $\mathrm{pH}, \mathrm{O} 2$ and $\mathrm{CO} 2$ concentrations and Some organic substances (Pierik, 1987).

Minerals are the next most important group of nutrient materials after sugars for in vitro growth. There is a large choice of combinations of macro- and micro-salt mixtures. The Murashige and Skoog (1962) medium is very popular, because most plants react to it favorably. However, it should be appreciated that this nutrient solution is not necessarily always optimal for growth and development (Cohen, 1995). Nutrients are essential for the growth and development of the plant: without water and mineral nutrients a plant cannot live in vitro or in vivo. Sugars must also be added to the culture medium, since plants (or parts of plants) in this condition, are not completely autotrophic. The importance of physical factors in growth and development in vivo is just as applicable in vitro. Potato plants need more light intensity and low temperature to improve the growth in vitro and overcome shoot tip necrosis.

The recent scientific work aimed to study the effect of MS salt strength, gelling agent (agar and gelrite) as well as calcium pantothenate and silver thiosulfate (STS) and light intensity as growth factors on in vitro growth and development of potato cultivars Santana and Innovator.

\section{Materials and Methods}

This work was conducted in Tissue Culture Centre, Genetic Engineering and Biotechnology Research Institute, University of Sadat City during the period from 2013 to 2016. Certified tubers of potato (Solanum tuberosum L.) cv. Santana and Innovator cultivars were used as plant material. The seed tubers were kindly obtained from Ministry of Agriculture 
(French Project). These tubers have been tested for brown rot bacterial disease and black leg caused by fungal infection in addition to circular root rot disease. The tubers were tested also against potato virus $\mathrm{X}$ (PVX), potato virus y (PVY) and potato leaf roll virus (PLRV).

Tubers were sprouted in dark at room temperature $\left(25 \pm 2{ }^{\circ} \mathrm{C}\right)$. When the sprouts had 3-5 nodes (4-5 cm length), they were removed from the tubers and surface sterilized by $10 \%(\mathrm{v} / \mathrm{v})$ Clorox (contained $5.25 \%$ of sodium hypochlorite) for $20 \mathrm{~min}$, then rinsed three times in sterile distilled water. Under binocular, meristem tips were excised in length about $0.5 \mathrm{~mm}$ were placed into tubes $(15.0 \times 2.5 \mathrm{~cm})$ which contained $20 \mathrm{ml}$ of MS (Murashige and Skoog,1962)medium supplemented with $0.10 \mathrm{mg} / \mathrm{l} \mathrm{Kinetin}$ and $1 \mathrm{mg} / \mathrm{l}$ indole acetic acid( IAA). Medium was solidified with 2 g/l gelrite. Subculture of growing meristem to a fresh medium was carried out every four weeks.

The effect of MS ( $1 / 4,1 / 2,3 / 4$ and full MS) salt strength as the main factor of nutrient medium affecting in vitro growth of two cultivars namely Innovator and Santana as well as gelling agent (agar and gelrite), was studied. Light intensity as a physical growth factors affecting the in vitro growth were also studied. The effect of calcium pantothenate and silver thiosulfate (STS) on in vitro growth and development of the previous two cultivars were studied too.

To improve the size of the leaves, the experiment was designed using sodium thiosulfate (STS) which prepared from silver nitrate and sodium thiosulfate according the method described by Elshobaky and Ibrahim(1997). In the experiment 0.25 0.50 and $1 \mathrm{mg} / \mathrm{l}$ were used to study the effect of STS on in vitro growth of potato plants.

\section{Statistical analyses}

The randomized factorial design was used and data were subjected to analysis of variance. Separation of means among treatments was determined using LSD test at 5\% (Steel and Torrie, 1980).

\section{Results and Discussion}

\section{Effect of MS media salt strength on in vitro growth and development of potato}

Data presented in Tables (1 and 2 ) clearly show the effect of MS salt strength on shoot and root formation of in vitro potato plants as well as shoot tip necrosis. The shoot tip necrosis is a phenomenon occurred in potato and some other plants during in vitro propagation and it could associated with media composition. That phenomena led to death of the plantlet shoot tips. We evaluated the necrosis effect as sever necrosis, strong or above moderate, moderate, below moderate and no effect.

\section{Innovator cultivar}

Data in Table (1) show that, there is no significant difference in plant length of the cultivar under different salt MS strength but the significantly effect was appeared in number of leaves where MS at full salt strength recorded the highest number of leaves comparing to other treatments. The opposite effect was occurred in root formation where 1/4 MS recorded the best result for root formation with significant difference among the treatments. Shoot tip necrosis was affected by MS salt strength. Nutrient medium containing low concentrations of salts increased shoot tip necrosis. It may be due to calcium deficiency in nutrient medium. In this case the full MS salts could be recommended to ovoid tip necrosis symptoms. 


\section{Santana Cultivar}

Data presented in Table (2) show significant effect of all parameters tested for in vitro growth of potato plantlets. Nutrient medium at full MS salt strength was the best for all shoot formation followed by $3 / 4$ MS while nutrient medium containing $1 / 4$ or $1 / 2 \mathrm{MS}$ was the best for root formation with significant difference among the treatments. Genetic make-up or plant cultivar type for in vitro potato plants was affected in vitro growth and development as shown in Table 1 for Innovator and in Table 2 for Santana cultivars. The number of nodes potato $\mathrm{cv}$. Agria in MS full strengths was higher than $1 / 2 \mathrm{MS}$ and $1 / 4 \mathrm{MS}$ media (Kazemiani et al., 2012).

Effect of gelling agent (agar and gellrite) on in vitro growth and development of potato

Different gelling compounds usually added to solidify the medium in tissue culture techniques, it includes agar and brand name of gelrite. The source of agar are the algae in water.In contrast gelrite produced through fermentation of Psudomonase bacteria. In this study both agent compound were compared.

Data in Tables (3 and 4) show the effect of agar + gelrite added to MS nutrient medium on in vitro growth of potato cultivars Innovator and Santana. Regarding innovator cultivar, there were significant differences among gelling agent treatments. Nutrient medium supplemented with $2.5 \mathrm{~g} / \mathrm{l}$ agar + $1 \mathrm{~g} / \mathrm{l}$ gelrite recorded the best growth for shoot formation estimated as plant length, shoot number and number of leaves as well as root number as shown in Table (3). The same trend was found for Santana cultivar as presented in Table (4). Result and discussion are in accordance with Elshobakey et. al.,
1993; Elshobakey and Ibrahim (1993); Ibrahim, 1994 and 2016; Ebrahim and Ibrahim,2000).

\section{Effect of light intensity on in vitro growth and development of potato}

Date in Tables (5 and 6) show the role of light intensity on in vitro growth of potato cv. Innovator and Santana. Data presented in Table (5) indicated that light intensity at 3000 lux recorded the best values of plant length $(10.333 \mathrm{~cm})$ compared to 1000 and 2000lux (7.667and9.00 $\mathrm{cm}$ respectively). There is no significant difference among all light intensity treatments on shoot number. While 3000 lux treatment gave the highest of the leaves number, root number and root length $(21.33,22.00$ and $11.33 \mathrm{~cm}$ respectively). There is no significant difference among all treatments on shoot tip necrosis.

Light intensity at 3000 lux recorded the best growth of Santana cultivar estimated as shoot number, number of leaves and root length with significant differences among the light intensities treatments as presented in (Table 6). Results under discussion are in line with Kitaya et al. (1995) From the previous results we can conclude that the best medium for in vitro growth of potato cultivars (Innovator and Santana) is MS basal medium at full salt strength solidified with $2.5 \mathrm{~g} / \mathrm{l}$ agar $+1 \mathrm{~g} / \mathrm{l}$ gelrite at 3000 Lux.

\section{Effect of calcium pantothenate on in vitro growth of potato plantlets}

Data presented in Tables 7 and 8 clearly show the role of calcium pantothenate on shoot tip necrosis phenomena which affecting in vitro growth and prevent burning of shoot tip (shoot tip necrosis). Shoot tip necrosis increased number of shoots with weak shoots, so the addition of 
calcium pantothenate prevented shoot tip necrosis and decreased number of shoots. it may be due to the balance between auxin and cytokinins where cytokinins increased and auxin decreased. The addition of calcium pantothenate improved the growth of potato plantlets as illustrated in photo (1). According to the importance of calcium pantothenate at $2 \mathrm{mg} / 1$, we used it to propagate all cultivars under study which improved the growth of potato plantlets for both purposes for microtuber formation or to acclimatization of potato plantlets.

Calcium pantothenate was found to overcome shoot tip necrosis and stimulate tissue proliferation of potato plantlets (Sha et al., 1985; George and Sherringon, 1984; Pireik, 1987; Elshobaki and Ibrahim, 1997). Generally calcium pantothenate improved the growth of Innovator and Santana cultivars and reduced or prevent shoot tip necrosis as shown in tables 7 and 8 and illustrated in photo (1).

Plant tissue culture plays an important role in the production and conservation of plant species. Its application, however, is hindered by some growth abnormalities such as shoot-tip necrosis (STN) caused by the culture conditions (Bairu et al. 2009).

\section{Effect of Silver Thiosulfate (STS )on in vitro growth of potato plantlets}

The size of potato leaves were affected by many factors affecting in vitro growth of potato plantlets during micropropagation stages. One of these factors is ethylene accumulation in test tube and prevent the uptake of calcium and subsequently the appearance of shoot tip necrosis and decrease the size of leaves. We try to improve the growth, prevent or reduce shoot tip necrosis by using calcium pantothenate as mentioned in the previous experiment.

To improve the size of the leaves, the experiment was designed using sodium thiosulfate (STS) which prepared from silver nitrate and sodium thiosulfate according the method described by Elshobaky and Ibrahim (1997). In the experiment $0.25-0.50$ and 1 $\mathrm{mg} / \mathrm{l}$ were used to study the effect of STS on in vitro growth of potato plants.

Table.1 Effect of MS media salt strength on growth and development of potato (Solanum tuberosum cv.Innovator).

\begin{tabular}{|l|c|c|c|c|c|c|}
\hline $\begin{array}{l}\text { MS Salt } \\
\text { strength }\end{array}$ & $\begin{array}{c}\text { Plant } \\
\text { length }(\mathbf{c m})\end{array}$ & $\begin{array}{c}\text { Shoot } \\
\text { number }\end{array}$ & $\begin{array}{c}\text { Leaves } \\
\text { number }\end{array}$ & $\begin{array}{c}\text { Root } \\
\text { number }\end{array}$ & $\begin{array}{c}\text { Root } \\
\text { length }(\mathbf{c m})\end{array}$ & $\begin{array}{c}\text { Shoot tip } \\
\text { necrosis }\end{array}$ \\
\hline $\mathbf{1 / 4 M S}$ & $10.667 \mathrm{a}$ & $13.667 \mathrm{ab}$ & $18.667 \mathrm{bc}$ & $19.333 \mathrm{a}$ & $8.667 \mathrm{a}$ & +++ \\
\hline $\mathbf{1 / 2 M S}$ & $9.667 \mathrm{a}$ & $11.000 \mathrm{ab}$ & $14.000 \mathrm{c}$ & $16.000 \mathrm{~b}$ & $8.333 \mathrm{a}$ & +++ \\
\hline $\mathbf{3 / 4 M S}$ & $9.333 \mathrm{a}$ & $10.000 \mathrm{~b}$ & $21.333 \mathrm{ab}$ & $12.667 \mathrm{c}$ & $6.333 \mathrm{~b}$ & - \\
\hline Full MS & $9.333 \mathrm{a}$ & $14.333 \mathrm{a}$ & $27.333 \mathrm{a}$ & $14.667 \mathrm{~b}$ & $7.667 \mathrm{a}$ & - \\
\hline LSD at 5\% level & $\mathrm{NS}$ & $\mathbf{3 . 8 0 0}$ & $\mathbf{6 . 5 1 4}$ & $\mathbf{1 . 4 3 7}$ & $\mathbf{1 . 0 8 0}$ & \\
\hline
\end{tabular}

Shoot tip necrosis were estimated as score: $1=-$ No shoot tip necrosis $2=+$ Below moderate shoot tip necrosis. $3=++$ Moderate shoot tip necrosis $4=+++$ above moderate shoot tip necrosis $5=++++$ Severe shoot tip necrosis. 
Table.2 Effect of MS media salt strength on in vitro growth and development of potato (Solanum tuberosum Cv. Santana)

\begin{tabular}{|l|c|c|c|c|c|c|}
\hline $\begin{array}{l}\text { MS Salt } \\
\text { Strength }\end{array}$ & $\begin{array}{c}\text { Plant } \\
\text { length }(\mathbf{c m})\end{array}$ & $\begin{array}{c}\text { Shoot } \\
\text { number }\end{array}$ & $\begin{array}{c}\text { Number } \\
\text { of leaves }\end{array}$ & $\begin{array}{c}\text { Root } \\
\text { number }\end{array}$ & $\begin{array}{c}\text { Root } \\
\text { length(cm) }\end{array}$ & $\begin{array}{c}\text { Shoot tip } \\
\text { necrosis }\end{array}$ \\
\hline 1/4MS & $5.667 \mathrm{~b}$ & $3.333 \mathrm{~b}$ & $20.333 \mathrm{~b}$ & $20.333 \mathrm{a}$ & $9.333 \mathrm{a}$ & - \\
\hline 1/2MS & $5.333 \mathrm{bc}$ & $6.000 \mathrm{a}$ & $22.667 \mathrm{ab}$ & $13.667 \mathrm{~b}$ & $8.333 \mathrm{~b}$ & + \\
\hline 3/4MS & $4.667 \mathrm{c}$ & $6.333 \mathrm{a}$ & $28.333 \mathrm{a}$ & $12.333 \mathrm{bc}$ & $7.333 \mathrm{~b}$ & + \\
\hline MS Full & $8.667 \mathrm{a}$ & $7.000 \mathrm{a}$ & $25.667 \mathrm{ab}$ & $11.667 \mathrm{c}$ & $7.333 \mathrm{~b}$ & ++ \\
\hline LSD at 5\% level & $\mathbf{0 . 8 9 8 5}$ & $\mathbf{5 . 1 5 3}$ & $\mathbf{6 . 1 0 2}$ & $\mathbf{1 . 9 6 4}$ & $\mathbf{1 . 1 6 0}$ & \\
\hline
\end{tabular}

Shoot tip necrosis were estimated as score: $1=-$ No shoot tip necrosis2 $=+$ Below moderate shoot tip necrosis. $3=$ ++ Moderate shoot tip necrosis $4=+++$ above moderate shoot tip necrosis $5=++++$ Severe shoot tip necrosis.

Table.3 Effect of gelling agent (agar and gelrite) on in vitro growth and development of potato (Solanum tuberosum cv.Innovator)

\begin{tabular}{|l|c|c|c|c|c|c|}
\hline Gelling agent $(\mathrm{g} / \mathrm{l})$ & $\begin{array}{c}\text { Plant } \\
\text { length } \\
\text { (cm) }\end{array}$ & $\begin{array}{c}\text { Number } \\
\text { of shoots }\end{array}$ & $\begin{array}{c}\text { Number } \\
\text { of } \\
\text { leaves }\end{array}$ & $\begin{array}{c}\text { Number } \\
\text { of roots }\end{array}$ & $\begin{array}{c}\text { Root } \\
\text { length } \\
\text { (cm) }\end{array}$ & $\begin{array}{c}\text { Shoot tip } \\
\text { necroses }\end{array}$ \\
\hline Liquid & $\mathbf{3 . 0 0 0 b}$ & $\mathbf{1 . 0 0 0 c}$ & $\mathbf{3 . 0 0 0 c}$ & $\mathbf{4 . 3 3 3 c}$ & $\mathbf{5 . 3 3 3 c}$ & - \\
\hline $\begin{array}{l}\mathbf{2 . 5 g} / \mathbf{l} \text { agar+1g/l } \\
\text { gelrite }\end{array}$ & $\mathbf{1 0 . 0 0 0 a}$ & $\mathbf{1 3 . 0 0 0 a}$ & $\mathbf{2 7 . 3 3 3 a}$ & $\mathbf{1 4 . 6 6 7 a}$ & $\mathbf{7 . 3 3 3 b c}$ & - \\
\hline 3g/l agar+1g/l gelrite & $\mathbf{9 . 0 0 0 a}$ & $\mathbf{1 0 . 6 6 7 a b}$ & $\mathbf{2 2 . 0 0 0 b}$ & $\mathbf{1 2 . 6 6 7} \mathrm{b}$ & $\mathbf{9 . 3 3 3 a b}$ & + \\
\hline $\begin{array}{l}\text { 3.5 g/l agar+1 g/l } \\
\text { gelrite }\end{array}$ & $\mathbf{9 . 0 0 0 a}$ & $\mathbf{8 . 0 0 0 b}$ & $\mathbf{2 2 . 0 0 0 b}$ & $\mathbf{1 3 . 6 6 7 a b}$ & $\mathbf{1 0 . 3 3 3 a}$ & ++ \\
\hline LSD at 5\% level & 2.139 & 2.935 & 4.183 & 1.037 & 2.139 & \\
\hline
\end{tabular}

Shoot tip necrosis were estimated as score: $1=-$ No shoot tip necrosis $2=+$ Below moderate shoot tip necrosis. $3=++$ Moderate shoot tip necrosis $4=+++$ above moderate shoot tip necrosis5 $=++++$ Severe shoot tip necrosis.

Table.4 Effect of gelling agent(agar and gellrite) on in vitro growth and development of potato ( Solanum tuberosumcv.Santana).

\begin{tabular}{|c|c|c|c|c|c|c|}
\hline Gelling agent $(\mathrm{g} / \mathrm{l})$ & $\begin{array}{l}\text { Plant } \\
\text { length } \\
(\mathrm{cm})\end{array}$ & $\begin{array}{l}\text { Shoot } \\
\text { number }\end{array}$ & $\begin{array}{l}\text { Number } \\
\text { of leaves }\end{array}$ & $\begin{array}{l}\text { Root } \\
\text { number }\end{array}$ & $\begin{array}{l}\text { Root } \\
\text { length } \\
\text { (cm) }\end{array}$ & $\begin{array}{l}\text { Shoot tip } \\
\text { necrosis }\end{array}$ \\
\hline Liquid & 8.333b & $6.333 a$ & $23.667 a$ & 8.333b & $9.667 \mathbf{a}$ & - \\
\hline $2.5 \mathrm{~g} / \mathrm{l}$ agar$+1 \mathrm{~g} / \mathrm{l}$ gelrite & 10.33a & 5.333a & $24.333 a$ & $11.667 a$ & 5.333b & - \\
\hline 3 g/l agar +1 g/l gelrite & $6.667 \mathrm{c}$ & $5.667 a$ & 24.333a & 8.000b & 3.333c & + \\
\hline $3.5 \mathrm{~g} / \mathrm{l}$ agar+1g/lgelrite & $6.000 \mathrm{c}$ & $3.667 b$ & 18.333b & 4.333c & $1.667 d$ & ++ \\
\hline LSD at $5 \%$ level & 1.340 & 1.080 & 1.556 & 2.054 & 0.7915 & \\
\hline
\end{tabular}

Shoot tip necrosis were estimated as score:1= - No shoot tip necrosis2 $=+$ Below moderate shoot tip necrosis. $3=++$ Moderate shoot tip necrosis $4=+++$ above moderate shoot tip necrosis5 $=++++$ Severe shoot tip necrosis. 
Table.5 Effect of light intensity on in vitro growth and development of potato (Solanum tuberosum cv. Innovator).

\begin{tabular}{|l|c|c|c|c|c|c|}
\hline $\begin{array}{l}\text { light } \\
\text { intensity } \\
\text { (Lux) }\end{array}$ & $\begin{array}{c}\text { Plant } \\
\text { length } \\
(\mathrm{cm})\end{array}$ & $\begin{array}{c}\text { Shoot } \\
\text { number }\end{array}$ & $\begin{array}{c}\text { Number } \\
\text { of leaves }\end{array}$ & $\begin{array}{c}\text { Root } \\
\text { number }\end{array}$ & $\begin{array}{c}\text { Root } \\
\text { length } \\
(\mathrm{cm})\end{array}$ & $\begin{array}{c}\text { Shoot tip } \\
\text { necroses }\end{array}$ \\
\hline 1000 Lux & $\mathbf{8 . 0 0 0 a}$ & $\mathbf{7 . 0 0 0 c}$ & $\mathbf{1 7 . 0 0 0 c}$ & $\mathbf{7 . 6 6 7 b}$ & $\mathbf{5 . 6 6 7 a}$ & ++ \\
\hline 2000 Lux & $\mathbf{5 . 6 6 7 b}$ & $\mathbf{8 . 3 3 3 b}$ & $\mathbf{2 2 . 3 3 3 b}$ & $\mathbf{9 . 0 0 0 b}$ & $\mathbf{5 . 3 3 3 a b}$ & ++ \\
\hline 3000 Lux & $\mathbf{5 . 3 3 3 b}$ & $\mathbf{1 4 . 6 6 7 a}$ & $\mathbf{3 3 . 6 6 7 a}$ & $\mathbf{1 4 . 0 0 0 a}$ & $\mathbf{4 . 3 3 3 b}$ & - \\
\hline LSD at 5\% level & $\mathbf{0 . 7 6 9 4}$ & $\mathbf{1 . 0 8 7}$ & $\mathbf{2 . 7 7 2}$ & $\mathbf{2 . 2 6 3}$ & $\mathbf{1 . 2 5 5}$ & \\
\hline
\end{tabular}

Shoot tip necrosis were estimated as score:1 $=$ - No shoot tip necrosis $2=+$ Below moderate shoot tip necrosis. $3=++$ Moderate shoot tip necrosis $4=+++$ above moderate shoot tip necrosis $5=++++$ Severe shoot tip necrosis.

Table.6 Effect of light intensity on in vitro growth and development of potato (Solanum tuberosum ( cv. Santana)

\begin{tabular}{|l|c|c|c|c|c|c|}
\hline $\begin{array}{l}\text { light intensity } \\
\text { (Lux) }\end{array}$ & $\begin{array}{c}\text { Plant } \\
\text { length } \\
\text { (cm) }\end{array}$ & $\begin{array}{c}\text { Number } \\
\text { of shoots }\end{array}$ & $\begin{array}{c}\text { Number } \\
\text { of leaves }\end{array}$ & $\begin{array}{c}\text { Number } \\
\text { of roots }\end{array}$ & $\begin{array}{c}\text { Root } \\
\text { length } \\
\text { (cm) }\end{array}$ & $\begin{array}{c}\text { Shoot tip } \\
\text { necrosis }\end{array}$ \\
\hline 1000 lux & $\mathbf{7 . 6 6 7 c}$ & $\mathbf{6 . 3 3 3 a}$ & $\mathbf{1 1 . 0 0 0 b}$ & $\mathbf{1 0 . 6 6 7 c}$ & $\mathbf{8 . 3 3 3 b}$ & ++ \\
\hline 2000 lux & $\mathbf{9 . 0 0 0 b}$ & $\mathbf{8 . 6 6 7 a}$ & $\mathbf{1 0 . 3 3 3 b}$ & $\mathbf{1 4 . 6 6 7 b}$ & $\mathbf{9 . 0 0 0 b}$ & + \\
\hline 3000 lux & $\mathbf{1 0 . 3 3 3 a}$ & $\mathbf{8 . 0 0 0 a}$ & $\mathbf{2 1 . 3 3 3 a}$ & $\mathbf{2 2 . 0 0 0 a}$ & $\mathbf{1 1 . 3 3 3 a}$ & - \\
\hline LSD at 5\% level & $\mathbf{0 . 7 6 9 4}$ & NS & $\mathbf{2 . 6 2 5}$ & $\mathbf{2 . 2 6 3}$ & 1.255 & \\
\hline
\end{tabular}

Shoot tip necrosis were estimated as score: $1=-$ No shoot tip necrosis2 $=+$ Below moderate shoot tip necrosis. $3=++$ Moderate shoot tip necrosis $4=+++$ above moderate shoot tip necrosis5= + +++ Severe shoot tip necrosis.

Table.7 Effect of calcium pantothenate on in vitro growth and shoot tip necrosis of potato (Solanum tuberosum cv. Innovator)

\begin{tabular}{|c|c|c|c|c|}
\hline $\begin{array}{l}\text { Calcium pantothenate } \\
\text { concentration } \mathrm{mg} / \mathrm{l}\end{array}$ & $\begin{array}{l}\text { Plant length } \\
\text { (cm) }\end{array}$ & $\begin{array}{l}\text { Number of } \\
\text { shoots }\end{array}$ & $\begin{array}{l}\text { Number of } \\
\text { leaves }\end{array}$ & $\begin{array}{c}\text { Shoot tip } \\
\text { necrosis } \\
\text { (STN) }\end{array}$ \\
\hline Control 0.0 mg/l & 8.833a & $4.000 a$ & $11.667 a$ & ++ \\
\hline 1mg/l & $6.667 b$ & $3.667 a b$ & $12.667 a$ & + \\
\hline $2 \mathrm{mg} / 1$ & $6.167 \mathrm{bc}$ & $2.667 \mathrm{bc}$ & 11.333a & - \\
\hline $3 \mathrm{mg} / 1$ & $3.667 d$ & $2.333 c$ & 9.333a & - \\
\hline $4 \mathrm{mg} / 1$ & $5.000 \mathrm{c}$ & $2.667 \mathrm{bc}$ & $14.00 \mathrm{a}$ & - \\
\hline $5 \mathrm{mg} / 1$ & $5.667 \mathrm{bc}$ & $2.000 c$ & $10.333 a$ & - \\
\hline LSD at 5\% level & 1.331 & 1.317 & NS & \\
\hline
\end{tabular}

Shoot tip necrosis were estimated as score:1= - No shoot tip necrosis2 $=+$ Below moderate shoot tip necrosis. $3=++$ Moderate shoot tip necrosis $4=+++$ above moderate shoot tip necrosis5 $=++++$ Severe shoot tip necrosis. 
Table.8 Effect of calcium pantothenate on in vitro growth of potato (Solanum tuberosum cv. Santana).

\begin{tabular}{|c|c|c|c|c|}
\hline $\begin{array}{l}\text { Calcium pantothenate } \\
\text { Concentration }(\mathrm{mg} / \mathrm{l})\end{array}$ & $\begin{array}{c}\text { Plant length } \\
(\mathrm{cm})\end{array}$ & $\begin{array}{l}\text { Number } \\
\text { of shoots }\end{array}$ & $\begin{array}{c}\text { Number of } \\
\text { leaves }\end{array}$ & $\begin{array}{c}\text { Shoot tip } \\
\text { necrosis }\end{array}$ \\
\hline Control & 10.000ab & 4.000ab & 18.33ab & + \\
\hline $1 \mathrm{mg} / \mathrm{I}$ & 9.333b & $2.333 c$ & $14.333 b$ & + \\
\hline $2 \mathrm{mg} / \mathrm{l}$ & $11.667 a$ & $2.333 c$ & $15.333 b$ & - \\
\hline $3 \mathrm{mg} / \mathrm{l}$ & $9.000 b$ & 4.000ab & 21.000ab & - \\
\hline $4 \mathrm{mg} / \mathrm{l}$ & $9.333 b$ & $4.667 a$ & 18.000ab & - \\
\hline $5 \mathrm{mg} / \mathrm{l}$ & $3.667 \mathrm{c}$ & $3.000 b c$ & $6.000 c$ & - \\
\hline LSD at $5 \%$ level & 2.062 & 1.322 & 4.862 & \\
\hline
\end{tabular}

Shoot tip necrosis were estimated as score: $1=-$ No shoot tip necrosis $2=+$ Below moderate shoot tip necrosis. $3=++$ Moderate shoot tip necrosis $4=+++$ above moderate shoot tip necrosis5 = + + ++ Severe shoot tip necrosis.

Table.9 Effect of silver thiosaulfate (STS) on in vitro growth of potato (Solanum tuberosum cv. Innovator)

\begin{tabular}{|l|l|l|l|l|l|l|l|}
\hline STS (mg/l) & $\begin{array}{l}\text { Plant } \\
\text { length } \\
\text { (cm) }\end{array}$ & $\begin{array}{l}\text { Number } \\
\text { of shoots }\end{array}$ & $\begin{array}{l}\text { Number } \\
\text { of leaves }\end{array}$ & $\begin{array}{l}\text { Root } \\
\text { number }\end{array}$ & $\begin{array}{l}\text { Root } \\
\text { length } \\
\text { (cm) }\end{array}$ & $\begin{array}{l}\text { Shoot } \\
\text { tip } \\
\text { necrosis }\end{array}$ & $\begin{array}{l}\text { Leaves } \\
\text { growth }\end{array}$ \\
\hline Control & $\mathbf{9 . 6 6 7 a}$ & $\mathbf{3 . 0 0 0 b}$ & $\mathbf{1 2 . 0 0 0 b}$ & $\mathbf{1 1 . 6 6 7 b}$ & $\mathbf{1 1 . 6 6 7 b}$ & + & ++ \\
\hline $\mathbf{0 . 2 5}$ & $\mathbf{1 1 . 3 3 3 a}$ & $\mathbf{7 . 3 3 3 a}$ & $\mathbf{2 5 . 0 0 0 a}$ & $\mathbf{1 5 . 3 3 3 a}$ & $\mathbf{1 4 . 0 0 0 a}$ & - & ++ \\
\hline $\mathbf{0 . 5 0}$ & $\mathbf{9 . 3 3 3 a}$ & $\mathbf{5 . 6 6 7 a b}$ & $\mathbf{1 2 . 6 6 7 b}$ & $\mathbf{8 . 3 3 3 c}$ & $\mathbf{9 . 3 3 3 c}$ & - & ++ \\
\hline 1.00 & $\mathbf{9 . 0 0 0 a}$ & $\mathbf{6 . 0 0 0 a}$ & $\mathbf{1 4 . 6 6 7 b}$ & $\mathbf{1 0 . 0 0 0 a}$ & $\mathbf{9 . 3 3 3 c}$ & - & + \\
\hline LSD at 5\% level & NS & $\mathbf{2 . 9 1 9}$ & $\mathbf{4 . 2 3 8}$ & $\mathbf{2 . 3 7 7}$ & $\mathbf{1 . 6 9 4}$ & & \\
\hline
\end{tabular}

Shoot tip necrosis were estimated as score: $1=-$ No shoot tip necrosis2 $=+$ Below moderate shoot tip necrosis. $3=++$ Moderate shoot tip necrosis $4=+++$ above moderate shoot tip necrosis5 $=++++$ Severe shoot tip necrosis. Leaves growth were estimated as score:: $1=-$ No leaves growth $2=+$ Below moderate leaves growth $3=++$ Moderate leaves growth $4=+++$ excellent leaves growth

Table.10 Effect of silver thiosulfate ( STS) on in vitro growth of potato plantlets (Solanum tuberosum cv. Santana).

\begin{tabular}{|l|c|c|c|c|c|c|c|}
\hline $\begin{array}{l}\text { STS } \\
\text { conc.ml/I }\end{array}$ & $\begin{array}{c}\text { Plant } \\
\text { length } \\
(\mathbf{c m})\end{array}$ & $\begin{array}{c}\text { Shoot } \\
\text { number }\end{array}$ & $\begin{array}{c}\text { Number } \\
\text { of leaves }\end{array}$ & $\begin{array}{c}\text { Root } \\
\text { number }\end{array}$ & $\begin{array}{c}\text { Root } \\
\text { length } \\
(\mathbf{c m})\end{array}$ & $\begin{array}{c}\text { Shoot } \\
\text { tip } \\
\text { necrosis }\end{array}$ & $\begin{array}{c}\text { Leaves } \\
\text { growth }\end{array}$ \\
\hline Control & $\mathbf{8 . 3 3 3 a b}$ & $\mathbf{1 3 . 3 3 3 a}$ & $\mathbf{4 2 . 3 3 3 a}$ & $\mathbf{1 2 . 6 6 7 a}$ & $\mathbf{1 1 . 3 3 3 a}$ & + & + \\
\hline $\mathbf{0 . 2 5}$ & $\mathbf{7 . 6 6 7 b}$ & $\mathbf{1 4 . 0 0 0 a}$ & $\mathbf{3 5 . 3 3 3 b}$ & $\mathbf{1 2 . 0 0 0 a}$ & $\mathbf{6 . 3 3 3 b}$ & + & ++ \\
\hline $\mathbf{0 . 5 0}$ & $\mathbf{9 . 0 0 0 a}$ & $\mathbf{1 0 . 0 0 0 b}$ & $\mathbf{3 8 . 6 6 7 a b}$ & $\mathbf{1 0 . 3 3 3 a}$ & $\mathbf{6 . 6 6 7 c}$ & - & +++ \\
\hline 1.00 & $\mathbf{8 . 6 6 7 a b}$ & $\mathbf{1 0 . 0 0 0 b}$ & $\mathbf{3 5 . 0 0 0 b}$ & $\mathbf{1 0 . 0 0 0 a}$ & $\mathbf{6 . 0 0 0 b}$ & - & + \\
\hline LSD at 5\% level & $\mathbf{1 . 2 3 5}$ & $\mathbf{2 . 5 5 9}$ & $\mathbf{5 . 8 6 2}$ & NS & $\mathbf{1 . 6 9 4}$ & & \\
\hline
\end{tabular}

Shoot tip necrosis were estimated as score: $1=-$ No shoot tip necrosis $2=+$ Below moderate shoot tip necrosis. $3=++$ Moderate shoot tip necrosis $4=+++$ above moderate shoot tip necrosis $5=++++$ Severe shoot tip necrosis. Leaves growth were estimated as score: $1=-$ No leaves growth $2=+$ Below moderate leaves growth $3=++$ Moderate leaves growth $4=+++$ excellent leaves growth 
Photo.1 In vitro potato plantlets grown on MS medium supplemented with $2 \mathrm{mg} / \mathrm{l}$ calcium pantothenate $+0.5 \mathrm{mg} / 1 \mathrm{STS}+30 \mathrm{~g} / \mathrm{l}$ sucrose $+2 \mathrm{mg} / 1$ glycine $+0.5 \mathrm{mg} / 1$ nicotinic acid $+0.5 \mathrm{mg} / \mathrm{l}$ pyrodoxin $+0.1 \mathrm{mg} / 1$ thiamin and solidified with $1 \mathrm{~g} / 1$ gelrite $+2.5 \mathrm{~g} / \mathrm{l}$ agar.

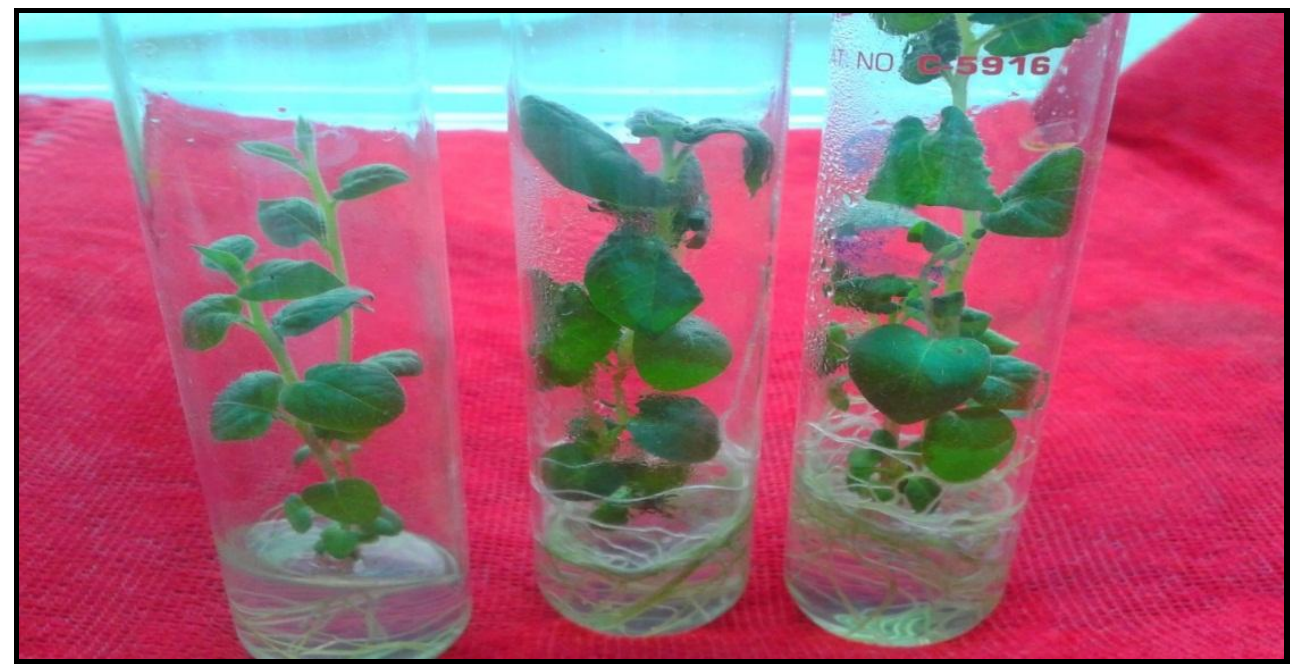

Data presented in Tables 9 and 10 show the effect of STS on in vitro growth and development of potato plants for Innovator and Santana cultivars. Silver thiosulfate at $0.5 \mathrm{ml} / 1$ from the solution mentioned before improved the growth for both cultivars because STS reduced the production of ethylene which affect in vitro growth of potato plantlets where complex silver ions inhibit ethylene action (Elshobaky and Ibrahim, 1997). The increase of STS concentration negatively affected in potato plantlets growth due to the toxicity of silver ion at high concentration. As shown in tables 9 and 10.the concentration of $0.5 \mathrm{mg} / \mathrm{l}$ is better than $1 \mathrm{mg} / 1$ to improve the in vitro growth of potato plantlets as illustrated in photo (1).

In this respect Perl et al., (1988) mentioned that ethylene release by potato shoots cultured in closed boxes was suppressed by the addition of silver thiosulfate to the culture medium. Shoots cultured in the presence of silver thiosulfate produced appreciably more tissue and the yield of protoplasts per unit tissue mass was vastly increased, resulting in an 8 fold increase of protoplast yield per shoot. Exposure of pricked leaves to macerating enzymes facilitated ethylene generation. Leaves of shoots which were previously cultured in silver thiosulfate containing medium generated much less ethylene than leaves from control shoots and this generation could be further reduced by the addition of acetylsalicylic acid during maceration.

\section{Protocol For Potato Propagation Through Tissue Culture}

From the previous results, we can conclude that to obtain good in vitro growth of potato plantlets (Photo, 1 ) suitable to acclimatization and microtuber formation, the protocol must be conducted according to the following points:

Explant: meristem tip (virus detection to PVX-PVY-PLRV-PVA-PVM -PVS), Nutrient medium $=M S+30 \mathrm{~g} / \mathrm{l}$ sucrose $+2 \mathrm{mg} / \mathrm{l}$ calcium pantothenate+0.5 $\mathrm{ml} / 1$ Silver Thiosulfate( STS ) $+0.5 \mathrm{mg} / 1$ nicotinic acid $+0.5 \mathrm{mg} / \mathrm{l}$ pyrodoxin+0.1 $\mathrm{mg} / \mathrm{l}$ thiamine+ 2 $\mathrm{mg} / 1$ glycine and solidified with $2.5 \mathrm{~g} / \mathrm{l}$ agar $+1 \mathrm{~g} /$ gelrite 
Physical growth factors: temperature $=22^{\circ} \mathrm{C}$ light intensity $=3000$ Lux

This protocol was conducted for all previous potato cultivars for mass production whether it was for potato acclimatization or microtubers formation and subsequently for minituber formation.

\section{References}

Abdelaleem, K.G. 2015. In vitro Organogenesis of (Solanum tuberosum L.) Plant Cultivar Alpha through Tuber Segment Explants Callus. Int. J. Curr. Microbiol. App. Sci., 4(2): 267276.

Bairu, M.W., Stirk, W.A., Staden, J. 2009. Factors contributing to in vitro shoottip necrosis and their physiological interactions. Plant Cell, Tissue and Organ Culture (PCTOC), 98: 239-248

COHEN, D. 1995. The culture medium. Acta Horticulturae, 393: 15-24

E1- Shobaky, S.A., Ibrahim, I.A.; and Ragab, M.A. 1993. Effect of gas exchange and sugar concentration on in vitro growth of potato (Solanum tuberosum) cv. Altcmtic. Minia $J$. Agric. Res. \&Dev., 15:497-504.

E1- Shobaky, S.A. and Ibrahim, I.A. 1993. Influence of agar concentration on in vitro growth of potato (Solanum tuberosum) cv. Cara. Minia J. Agric. Res. \& Dev. 15:487-494.

Ebrahim, M.K., Ibrahim, I.A. 2000. Influence of medium solidification and $\mathrm{pH}$ value on in vitro propagation of Maraanta leuconeura cv. Kerchoviana. Scientia Horticultura, 86: $211-221$.

El-Shobaky, S.A. and Ibrahim, I.A. 1997. Effect of silver thiosulphate and indole butyric acid on potato growth through tissue culture techinques. Zagazig J. Agric. Res., 24: 661-673.
George, E.F. and P.D. Sherrington. 1984. Plant propagation by tissue culture. Exigeties Ltd, England.

Ibrahim, I.A. 1994. Effect of gelling agent (Agar and Gelrite) and activated charcoal on the growth and development of Cordyline terminalis cultured in vitro. The first Conference of Ornamental Horticulture 1: 55-67, Cairo Egypt.

Ibrahim, I.A. 2016. Production of Potato Seeds Using Biotechnological Methods in New Valley. $1^{\text {ST }}$ International Conference of Genetic Engineering and Biotechnology. Integrative Science and Biotechnology, Sharm El-SheikhEgypt.

Kazemiani S., A. Motallebi-Azar, N. Mohaddes, F. Kiomarsy ,F. Yarmohammadi And F. Etedali. 2012. Effect of different concentrations of sucrose and bap on shoot proliferation on ms strength basal media in potato cv. Agria. South Western J. Horticulture, Biol. Environ., 3(1): 6372.

Khatun, N., Bari, M.A., Islam, R., Huda, S., Siddique, N.A., Rahman, M.H., Mollah, M.U. 2003. Callus induction and regeneration from nodal segment of potato cultivar Diamant, J. Biol. Sci., 3: 11011106.

Kitaya, Y., Fukuda, O., Kozai, T. and Kirdmanee, C. 1995. Effects of light intensity and lighting direction on the photoautotrophic growth and morphology of potato plantlets in vitro. Scientia Horticulturae, 62(1): 15-24.

Murashige, T. and Skoog, F. 1962. A revised medium for rapid growth and bioassay with tobacco tissue. Physiol. Plant, 15: 473-497.

Perl, A., Aviv, D., Galun, G. 1988. Ethylene and in vitro culture of potato: 
suppression of ethylene generation vastly improves protoplast yield, plating efficiency and transient expression of an alien gene. Plant Cell Rep., 7(6): 403-406.

Pierik, R.L.M. 1987. In vitro culture of higher plants. Martinus Ny Hoff. Publ, Dardrecht.

Sha, L., McCown, B.H., Peterson, L.A.
1985. Occurrence and cause of shoottip necrosis in shoot cultures. $J$. Am. Soc. Hortic. Sci., 110: 631-634.

Steel, R.G.D. and J.H. Torrie. 1980. Principles and procedures of statistics, a biometrical approach. Second Edition. McGraw-Hill Book Co., New York, NY, pp 137-177.

\section{How to cite this article:}

Ibrahim A. Ibrahim, H.A. Emara, A.A. Nower and Abodiab, A.Y. 2016. In vitro Cultivation of Potato Plants. Int.J.Curr.Microbiol.App.Sci. 5(12): 858-868. doi: http://dx.doi.org/10.20546/ijcmas.2016.512.094 